\title{
Kulturowo, lokalnie. Kilka uwag o badaniu literatury polskiej po II wojnie światowej
}

Jan Galant

Pisanie o literaturze $\mathrm{PRL}^{1}$ wymaga pokonania trudności trojakiego (co najmniej) rodzaju. Pierwsze są natury metodologicznej i wiążą się z dyskusyjnym współcześnie statusem humanistyki. W ostatnich kilku dziesięcioleciach utraciła ona pewność języka, którego neutralności nie sposób zakładać, i przedmiotu badań, czyli samej literatury, której granice uległy daleko idącemu przesunięciu, obejmując zwłaszcza obszary kultury popularnej, masowej. Są to więc trudności wewnętrzne tkwiące w samej dyscyplinie.

Specyfiką badań nad literaturą PRL są natomiast trudności o charakterze ideologicznym i poznawczym. Ideologiczne uwikłanie opowieści o PRL jest pochodną - co do tego krytycy pozostają zgodni - faktu, że pytanie o PRL jest zawsze pytaniem o dzisiejsze skutki istnienia tamtego państwa. Jak pisze Przemysław Czapliński: „opowiadamy o PRL-u i o sobie w PRL-u po to, by wyznaczyć własną pozycję w sporze o PRL i swoje miejsce w postkomunistycznej Polsce. Nie spieramy się o wizerunki dawnego świata, lecz o dzisiejsze konsekwencje, które z danego wizerunku wynikają"2. Skutkiem tych działań jest mocno stereotypowy obraz minionej epoki, w zależności od potrzeby przybierający kształt opresyjnego systemu (z jednej strony) lub „wesołego baraku" (na drugim biegunie).

Poznawcze ograniczenia wynikają natomiast $\mathrm{z}$ faktu, że opis kultury powojennej weryfikowany jest często przez władzę pamięci, budującej często trudny do zweryfikowania, odmienny mocno sprywatyzowany - obraz tamtych czasów. Jako główną tendencję w literaturze przedstawiającej okres PRL tę dominację indywidualnego doświadczenia wskazywał między innymi

\footnotetext{
${ }^{1}$ Dla wygody będę posługiwał się takim określeniem, na boku pozostawiam kwestię nazewnictwa tego okresu, mając świadomość istniejących propozycji i towarzyszących im uzasadnien.

${ }^{2}$ P. Czapliński, Polska do wymiany. Późna nowoczesność i nasze wielkie narracje, Warszawa 2009, s. 120.
} 
Dariusz Nowacki w znanym artykule Widokówki z tamtego świata. Pisał w nim, że „W prozie polskiej lat 90. temat PRL-u w zasadzie nie pojawia się inaczej niż jako problem «obecność w PRL-u» (problem uwikłania jednostki w tamtą rzeczywistość)"3.

Poza wszystkim, biblioteka opracowań poświęconych literaturze po II wojnie światowej jest przecież imponująca. Publikacji o charakterze syntetycznym, sumującym, z ambicjami całościowymi jest wśród nich sporo: Nadwiślański socrealizm Zbigniewa Jarosińskiego, który w dużym skrócie opisywał lata stalinowskie i czas odwilży; podręcznik tego samego autora w ramach serii Mała Historia Literatury Polskiej - Literatura lat 1945-1975; w tej samej serii Literatura okresu przejściowego 1975-1996 Anny Nasiłowskiej; dzieje poezji powojennej jeszcze w latach osiemdziesiątych omówił Edward Balcerzan w dwuczęściowej Poezji polskiej w latach 1939-1965, uzupełnionej książką Poezja polska po 1968 roku Anny Legeżyńskiej i Piotra Śliwińskiego; jest znane opracowanie Przemysława Czaplińskiego i Piotra Śliwińskiego Literatura polska 1976-1998. Przewodnik po prozie i poezji; wspomnieć wypada o wykładach Tadeusza Drewnowskiego, które złożyły się na tom Próba scalenia - obiegi, wzorce, style. Literatura polska 1944-1989. Są także liczne opracowania powstałe przed rokiem 1989, jak choćby Literatura polska 1918-1975 pod redakcją Aliny Brodzkiej. A jeszcze słowniki i leksykony! Urywam to wyliczenie, mając świadomość, że jest niekompletne, że nie sposób wymienić choćby ułamka opracowań szczegółowych, poświęconych poszczególnym pisarzom, utworom, nurtom czy grupom literackim, opracowań będących przykładem aplikowania współczesnych języków badawczych (krytyka postkolonialna, feminizm) w celu ponownej lektury dzieł powojennej literatury polskiej.

Dlatego chciałbym zatrzymać się przy dwu koncepcjach pisania o historii literatury, które moim zdaniem z powodzeniem można zastosować do interpretacji literatury okresu PRL, choć - na szczęście - nie tylko do niej. Pomijam przy tym te propozycje, które odwołują się do dostępnych obecnie języków i teorii, tworzących bogatą listę współczesnych zwrotów naukowych. W niektórych wypadkach dokonuje się - by przywołać sformułowanie Ryszarda Nycza „całkowita destylacja abstrakcyjnych formuł z zanieczyszczeń historycznego doświadczenia”.

Sięgam natomiast do rozwiązań, jakie pojawiają się w rozważaniach na temat kulturowej historii literatury, mającej być, jak rozumiem założenia, sposobem odświeżenia narracji historycznoliterackiej w zmienionych warunkach funkcjonowania badań literackich i samej literatury. Wyzwania i ograniczenia, przed jakimi stoi badacz literatury PRL, są bowiem, jak sądzę, identyczne z tymi, które próbuje przekraczać współczesna historia literatury.

\section{A single year study}

Jak przekonuje Włodzimierz Bolecki, pojęcie kulturowej historii literatury dalekie jest od precyzji, nie wiąże się z nim jasno wykreślona metodologia i zasób właściwych terminów oraz procedur. Jest raczej zbiorczą nazwą obejmującą istniejące już praktyki badawcze, wyrosłe z doświadczeń i zwrotów współczesnej humanistyki. Ten nie projektujący, lecz sumujący czy

\footnotetext{
${ }^{3}$ „Znak” 2000, nr 7.

${ }^{4}$ R. Nycz, PRL: pamięć podzielona, społeczeństwo przesiedlone, „Teksty Drugie” 2013, nr 3, s. 8.
} 
integrujący wymiar kulturowej historii literatury podkreśla Bolecki, kiedy zauważa, że jest ona „propozycją nazwania ogromnego już zbioru działań i badań, które nie od dziś powodują wątpliwości, czy to, co robimy, jest jeszcze «historią literatury», czy może już czymś zupełnie innym”. Użycie przymiotnika „kulturowy” wskazuje na zmiany, jakie zaszły w dzisiejszym uprawianiu historii literatury w stosunku do modelu obowiązującego przed laty.

O przyczynach, charakterze i przebiegu tych zmian pisano już wielokrotnie, wystarczy zatem jedynie hasłowo przypomnieć, że wpłynęły na nie: przekonanie o braku neutralności języka używanego w humanistyce, zmiana przedmiotu badań literaturoznawczych będąca konsekwencją rozszerzenia znaczenia terminu literatura, który obejmuje w tej chwili chyba wszelkie formy aktywności tekstowej, wreszcie, zacieranie się granic dyscyplin w humanistyce, najłatwiej dostrzegalne w powszechnych zapożyczeniach terminologicznych.

Kulturowa historia literatury zatem, w uproszczeniu, byłaby odmianą badań historycznoliterackich uwzględniającą powyższe okoliczności - a zatem refleksyjnie spoglądającą na zależność obrazów przeszłości od użytych kategorii opisowych i porządkujących, kierującą swe zainteresowanie w stronę wszelkich form znaczącej aktywności twórczej, adaptującą dla opisu tej aktywności terminy i metody stosowane $\mathrm{w}$ innych obszarach humanistyki. Jednym słowem - jeszcze raz odwołam się do Boleckiego: „Kulturowa historia literatury to po prostu zbiór zagadnień, które łączą historię literatury (w dzisiejszym rozumieniu) z historią kultury/ kultur (w dzisiejszym rozumieniu) lub, inaczej mówiąc, pozwalają opisywać historie literackie jako zjawiska kulturowe"6.

Jednym z ciekawszych wątków w badaniach nad kulturą PRL w tym kontekście są analizy mechanizmów konstruowania pojęć i kategorii poznawczych w przeszłości, poczynając od ogólnych (np. awangarda) do bardziej szczegółowych (zawartych w programach krytycznych, manifestach artystycznych). Dotyczy to zarówno sfery samowiedzy twórców (immanentnie obecnej w dziełach oraz wyeksplikowanej w wypowiedziach programowych, krytycznych), jak również terminologii polonistycznej stosowanej w określonym czasie lub przez poszczególnych badaczy (przykładem mogą służyć opracowania poświęcone Kazimierzowi Wyce jako krytykowi i badaczowi literatury). Znaczenie tego rodzaju refleksji upatruję w możliwości wyjaśnienia związku między rozpowszechnionymi przez długie lata wyobrażeniami na temat dawnej i współczesnej literatury polskiej a stosowanymi przez literaturoznawców pojęciami, tradycjami badawczymi, szkołami teoretycznymi.

Przede wszystkim jednak perspektywa kulturowa w odniesieniu do literatury PRL widoczna jest w publikacjach, które bazują na materiale różnorodnym, pochodzącym z różnych obszarów sztuki; które nie stronią od analizy zachowań, praktyk codzienności, reguł estetyzacji otoczenia (ubiory, plakaty, architektura, sztuka użytkowa itp.). Świetnym przykładem jest chociażby znana książka Iwony Kurz Twarze w tłumie. Wizerunki bohaterów wyobraźni zbiorowej w kulturze polskiej lat 1955-1969 (Warszawa 2005), która analizuje mechanizmy peere-

\footnotetext{
${ }^{5}$ W. Bolecki, Literackie historie kultury, [w:] Kulturowa historia literatury, red. A. Łebkowska, W. Bolecki, Warszawa 2015, s. 10.

${ }^{6}$ Tamże, s. 13.
} 
lowskich reguł kreowania gwiazd (bohaterami kolejnych rozdziałów są Marek Hłasko, Zbigniew Cybulski, Elżbieta Czyżewska, Kalina Jędrusik, Jerzy Skolimowski), sięgając do filmów i kronik filmowych, prasy literackiej, ale także ówczesnej prasy kolorowej, anegdoty środowiskowej. Dzięki temu możemy śledzić przesuwanie się granic skandalu obyczajowego, sposoby adaptowania do peerelowskiej rzeczywistości zachowań gwiazd Hollywoodu, siłę partyjnego purytanizmu, zderzanie zachowań artystycznych z wymogami propagandy.

Nie stosowaną na większą skalę, a interesującą, konwencją wypowiedzi literaturoznawczej, w której ten nie mający właściwie granic zbiór tekstów, zdarzeń, procesów składających się na PRL mógłby znaleźć swoje logiczne miejsce, jest znane w praktyce anglosaskiej „studium jednego roku” (single year study). Jak pisze Krzysztof Kłosiński - „żywioł narracyjny zastąpiony w nim zostaje przez spojrzenie synchroniczne" ${ }^{\text {" }}$, umożliwia przekroczenie współczesnych ograniczeń dyscypliny, przedmiotu badawczego i języka. Zakładany i jednocześnie nieosiągalny „wszystkoizm” daje jednocześnie poczucie (złudzenie?) pewnej elementarnej całości, wolnej od arbitralności wyboru i badawczej narracji.

Fakt, że zazwyczaj studium jednego roku posiada - by tak rzec - zbiorowego bohatera, a zasadą opowieści jest symultaniczność, sprawia, że może ono stanowić podstawę współczesnej wersji syntezy historycznoliterackiej, pozbawionej jednakże tego, co było kręgosłupem dawnych ujęć - określonej wizji procesu historycznoliterackiego, hipotezy dotyczącej kierunku przemian dziejów literatury, a więc możliwości prognozowania literackiej przyszłości. Anna Łebkowska wspomina o trzech syntezach historycznoliterackich (A New History of French Literature, 1989; A New History of German Literature, 2004; A New Literary History of America, 2009), w których takie warunki udało się spełnić: „Jednocześnie przeszłość nie zostaje w nich ujęta ani w idealistyczne systemy, ani w polityczne wykładnie, ani też w modele pretendujące

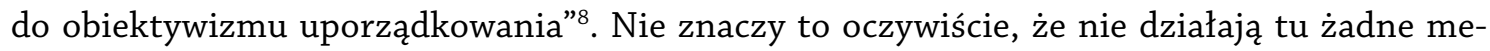
chanizmy porządkujące - selekcja materiału, sam wybór dat, ustanawia hierarchię wydarzeń, sygnalizuje punkty w przeszłości znaczące bardziej niż inne, albo też istotne ze względu na to, że przecinają się w nich w sposób szczególnie intensywny różnorodne zjawiska literackie i kulturowe (na przykład momenty przesileń politycznych lub przełomów społecznych). Łebkowska zwraca uwagę, że tom poświęcony historii literatury amerykańskiej (lub literackiej historii Ameryki, bo taka dwuznaczność tkwi w tytule) różni się od dwu pozostałych znaczącym poszerzeniem granic literatury.

Innym przykładem studium jednego roku jest książka Hansa Ulricha Gumbrechta In 1926: living on the edge of time z 1998 roku $^{9}$, której poszczególne rozdziały (a czytelnik zachęcany jest do lektury nielinearnej) dotyczą najróżniejszych zjawisk i sfer życia tamtego (nie)szczególnego roku: walk bokserskich, samolotów, kin, Ligi Narodów, ale także zagadnień ogólnych (autentyczności i sztuczności, indywidualności i zbiorowości, działania i bierności, centrum

${ }^{7}$ K. Kłosiński, „O roku ów”. Rokowania historii literatury, [w:] Kulturowa historia literatury, s. 255.

${ }^{8}$ A. Łebkowska, Przyszłość literatury wpisana w jej historię (wiek XX i czasy współczesne), [w:] Kulturowa historia literatury, s. 50. Każdy z wymienionych tomów to zbiór artykułów, uporządkowanych w formie swoistego kalendarium, którego poszczególnymi ogniwami są daty związane zdaniem autorów z ważnym wydarzeniem dla zbiorowości.

${ }^{9}$ We wspomnianym artykule Kłosińskiego znajdziemy omówienie nie tylko tej książki, ale jeszcze kilku innych. K. Kłosiński, „O roku ów”. Rokowania historii literatury. 
i peryferii) i mają się złożyć na portret określonego momentu historycznego. Wydawca tak reklamował książkę:

Wracamy do roku 1926 i doświadczeń, które wywołały w ludziach poczucie, że żyją na skraju czasu. Dotykamy świata, w którym prędkość wydawała się istotą życia. To rok, wobec którego nie mamy żadnych oczekiwań. To nie był rok 1066 czy 1588 czy 1945, ale był to rok, w którym A.A. Milne opublikował Kubusia Puchatka, a Alfred Hitchcock wyreżyserował swój pierwszy udany film Lokator. Pracują współcześni mistrzowie: Jorge Luis Borges, Babe Ruth, Leni Riefenstahl, Ernest Hemingway, Josephine Baker, Greta Garbo, Franz Kafka, Gertrude Stein, Martin Heidegger - a w tym samym czasie swoje codzienne obowiązki wykonywali pracownicy fabryk, sekretarki, inżynierowie, architekci i argentyńscy hodowcy bydła ${ }^{10}$.

Warto również przywołać jedną uwagę poczynioną przez Gumbrechta we wstępie do In 1926 autor mówi tam, że

Główna intencja książki została najlepiej uchwycona w zdaniu, które było jej początkowym podtytułem: „esej o historycznej jednoczesności”. Książka pyta, w jakim stopniu i jakim kosztem można ponownie uczynić teraźniejszymi [to make present again], w tekście, światy, które istniały przed urodzeniem jej autora - a autor jest w pełni świadomy, że takie przedsięwzięcie jest niemożliwe ${ }^{11}$.

Cytuję ten fragment, dostrzegając w nim wyraz zasadniczej motywacji i celu działań stojących za publikacjami utrzymanymi w konwencji studium jednego roku. Jest nim pragnienie, aby przeszłość na chwilę stała się teraźniejszością, to znaczy, aby można było dziś doświadczyć tego, jak było kiedyś. Dlatego potok zdarzeń, w którym zanurzony był człowiek żyjący przed laty, dla którego stanowiły one teraźniejszość, nie uporządkowaną, wielopostaciową, należy opowiedzieć w sposób, który współczesnego czytelnika postawi w identycznej sytuacji. Formuła, którą posłużył się Gumbrecht: „to make worlds present again”, wydaje się wyjątkowo uzasadniona. Wieloznaczność słowa „present” pozwala powiedzieć, że autor dzięki swojej pracy przedstawił, opowiedział o przeszłości, ale przede wszystkim uczynił ją teraźniejszością, sprawił, że stała się ona dzisiaj obecna (tu widzieć trzeba najważniejszy efekt owego wszystkoizmu single year studies), i tą możliwością zanurzenia się w minionym, jakby było ono wciąż obecne, obdarował czytelnika.

Taką właśnie intencję - przybliżenia, unaocznienia przeszłości odnajduję również w znanym artykule Jeden dzień w socrealizmie Jacka Łukasiewicza („Teksty Drugie” 2000/1-2) oraz w filmie dokumentalnym Macieja Drygasa Jeden dzień w PRL (z 2006 roku), co uprawnia przypuszczenia, że na niej zasadzają się główne walory poznawcze tej formy pisania o przeszłości, oraz, że pragnienie doświadczenia (bardziej niż rozumienia) przeszłości jest kluczowym oczekiwaniem czytelniczym.

Szkic Łukasiewicza stanowi próbę odtworzenia jednego dnia - 14 listopada 1951 roku - poprzez prasowe teksty, które można było tego dnia przeczytać. Ma więc charakter prasówki, referuje zawartość wrocławskich gazet, tak jak widział je i czytał ówczesny przeciętny obywatel.

\footnotetext{
${ }^{10}<$ http://www.hup.harvard.edu/catalog.php?isbn=9780674000551> [dostęp: 14.07.2017], tłumaczenie własne.

${ }^{11}$ H.U. Gumbrecht, In 1926: living at the edge of time, Cambridge-London 1997, s. XIV, tłumaczenie własne.
} 
Jeden dzień w socrealizmie to dzień spędzony w odbiciu. Dzień czytelnika (słuchacza, widza). $\mathrm{Z}$ różnego rodzaju podsuwanych mu tekstów zespalał on sobie tekst własny. Rekonstruuję - nie w pełni oczywiście - jeden z takich możliwych tekstów własnych, powstałych 14 listopada $1951 \mathrm{r}$. we Wrocławiu. Przede wszystkim rekonstruuję go na podstawie lektury czasopism, jakie mieszkaniec Wrocławia dnia tego czytał, a może raczej przerzucał ${ }^{12}$.

Celem tej rekonstrukcji jest rzecz jasna zdemaskowanie zmanipulowanego obrazu rzeczywistości, jaki wyłaniał się z tej propagandowej lektury. Jak widać, nad historyczne uogólnienie i opisową charakterystykę słusznie minionej epoki (choć z racji obecności podmiotu referującego i oceniającego zawartość dawnych gazet nie udało się ich wyeliminować) Łukasiewicz przedkłada przybliżenie codzienności, a w ten sposób daje możliwość doświadczenia życia w socrealizmie ${ }^{13}$.

Podobny efekt wywołuje film dokumentalny Macieja Drygasa Jeden dzień $w P R L^{14}$, który za pomocą kolażu materiałów archiwalnych (filmów, amatorskich nagrań, odczytanych dokumentów, raportów, donosów, notatek) odtwarza jeden dzień od świtu do zmierzchu: 27 września 1962. Podobnie jak w przypadku tekstu Łukasiewicza jest to dzień, w którym nic szczególnego się nie wydarzyło, nie miały miejsca wydarzenia, które kroniki XX wieku powinny odnotować. Archiwalne pochodzenie materiałów ma zaświadczać o autentyczności wyłaniającego się obrazu ówczesnej Polski oraz o neutralności samej opowieści. Natomiast wybór dnia pozwolił reżyserowi uniknąć nieuchronnych odwołań do znanej już historii, uwarunkowań ekonomicznych itp. Najważniejszy z interesującego mnie tutaj punktu widzenia jest przede wszystkim potencjał identyfikacji. Pisząca o filmie Małgorzata Kozubek twierdzi, że jego źródłem jest perspektywa powszedniości:

Maciej Drygas, interesując się „zwykłym” człowiekiem, o którym nikt nie pamięta, otwiera większe pole dla identyfikacji. Bada świadomość „zwykłych ludzi”. Przypomina coś, co jest nieznane młodszemu odbiorcy, ale jednocześnie odwołuje się do tego rodzaju pamięci, którą dysponują ludzie żyjący w tamtych czasach ${ }^{15}$.

Jako podsumowanie wyraźnej potrzeby doświadczenia PRL-u jako sposobu na zrozumienie tamtych czasów, a jednocześnie jako przykład skrajnej postaci tej potrzeby, pragnę przywołać książkę, która dokumentuje pewien eksperyment, jaki przeprowadziło dwoje dziennikarzy, Izabela Meyza i Witold Szabłowski. Postanowili oni przez pół roku żyć „jak w PRL”. Zapisem

${ }^{12} \mathrm{~J}$. Łukasiewicz, Jeden dzień w socrealizmie, „Teksty Drugie” 2000, nr 1/2, s. 7.

${ }^{13}$ Tak ten zamysł streszcza Michał Głowiński w recenzji książki: „Jacek Łukasiewicz zastanawia się nad tym, z czym zetknąć się mógł mieszkaniec Wrocławia 14 listopada roku 1951, gdy sięgnął po prasę lokalną i ogólnopolską w tym mieście dnia tego dostępną. O czym go powiadamiano, co podawano mu do wierzenia, jakie historyjki mu ku pouczeniu przedstawiano” („Pamiętnik Literacki” 2009, z. 1, s. 216).

${ }^{14}$ Reż. M. Drygas, Polska 2006.

${ }^{15}$ M. Kozubek, Jeden film z PRL-u. Maciej Drygas jako historyk kultury?, „Dyskurs. Pismo Naukowo-Artystyczne ASP we Wrocławiu" 2013, t. 16, s. 50. Na potwierdzenie tego potencjału identyfikacji, przybliżania dawnego doświadczenia, przytoczę słowa poświęcone filmowi zamieszczone na jednym z portali internetowych: „Dzięki dokumentom przedstawionym w obrazie Macieja Drygasa można dowiedzieć się więcej na temat systemu totalitarnego, niż z setek książek czy filmów traktujących o tamtych czasach. [...] Momenty wzruszające, śmieszne, smutne - wszystko to układa się w porażający autentyzmem obraz lat $60 . . . "$ ( $<$ http://culture.pl/pl/ dzielo/jeden-dzien-w-prl> [dostęp: 14.07.2017]). 
tego przedsięwzięcia jest książka Nasz mały PRL. Pót roku w M-3 z trwała, wąsami i maluchem (Kraków 2012). Klęska pomysłu wydaje mi się dość oczywista - nie sposób zrekonstruować tamtych czasów w zakresie przekraczającym niewielkie mieszkanie (podobnie było w znanym filmie Wolfganga Beckera Good bye, Lenin z 2003 roku), a to oznacza, że odtwarza się jedynie rekwizyty codzienności - meble, pieluchy, samochód, strój. Wnioski, które z eksperymentu płyną, nie są zaskakujące: zmiany technologiczne przyniosły wiele ułatwień w sferze codziennej egzystencji, dzisiejsze samochody są większe, jednorazowe pieluchy ułatwiają życie rodzicom, ubrania szyje się z lepszych materiałów. Dlatego przede wszystkim warto widzieć w $\mathrm{Na}$ szym małym $P R L-u$ świadectwo przekonania, że dostęp do przeszłości jest możliwy właściwie wyłącznie poprzez próbę powtórzenia doświadczeń.

W przedstawionych sposobach omawiania literackiej przeszłości uderza nie tylko łatwość, z jaką literatura rozpływa się wśród najróżniejszych tekstów kultury, stając się jednym z wielu nośników minionego doświadczenia, ale również wpisana w te sposoby niechęć do formułowania hipotez dotyczących ukrytych mechanizmów epoki, podskórnych procesów społecznych czy literackich. Maskujący własną hierarchiczność i selektywność „obraz przeszłości” sprawia wrażenie kompletnego, ale ta kompletność, zastępując uogólnienie, konceptualizację, nie ułatwia wpisania przedstawionych wydarzeń w szerszy proces historyczny czy historycznoliteracki, ba, właściwie z góry powściąga pokusę tworzenia takich całości. $W$ istocie rzeczy mamy bowiem do czynienia z wypowiedziami, które z definicji zamykają się w obrębie określonego, wybranego momentu w czasie. To nieuchronnie unieważnia historię - izolowane punkty, poszczególne pojedyncze dni nie są w stanie złożyć się na proces dziejowy o większej skali. W jego miejsce, w miejsce historii wkracza w takiej sytuacji mikroskala codzienności, perspektywa pojedynczego „szarego” człowieka, materiał pamięci.

\section{Literatura PRL w perspektywie regionalnej}

Propozycją historii literatury zdolnej sprostać wyzwaniom zmieniającego się świata (rozmyte granice literatury), zastąpić tradycyjny model uprawiania historii literatury (neutralność języka, wątpliwy scjentyzm), wreszcie zaspokoić potrzebę poznania bazującego na doświadczeniu jest również idea badań historycznoliterackich w perspektywie regionalnej, czy szerzej: geopoetyki. Zachętę do wykorzystania na użytek historii literatury terminologii, celów, założeń teoretycznych badań nad kulturą lokalną, regionalizmem, kulturą pogranicza (i transgranicza), relacjami centroperyferyjnymi znaleźć można między innymi w kilku artykułach Ryszarda Nycza.

Wychodząc w Możliwej historii literatury od opisu uwarunkowań badań historycznoliterackich - do wymienionych już tutaj należy dodać dezaktualizację narodowego modelu historii literatury (bazującego na jedności narodowej, językowej i terytorialnej) oraz kryzys poznania historycznego - Nycz wskazuje na trzy inspiracje nowej historii literatury: koncepcję systemów światowych, teorie postkolonialne oraz te konceptualizacje procesów globalizacyjnych, które zmuszają do uważniejszego traktowania zjawisk lokalnych i relacji centrum - peryferie. Tę ostatnią możliwość uzupełnia i rozwija problematyka pogranicza. W innym miejscu tę problematykę uzupełnia badacz o kwestie przesiedleń, migracji, widząc w nich kluczowe procesy społeczne po II wojnie światowej, a to pozwala dostrzec w kulturze i literaturze PRL 
zapis doświadczenia społeczeństwa pozbawionego swojego miejsca: „powojenne polskie społeczeństwo jest społeczeństwem przesiedlonym, zdeterytorializowanym, zdyslokowanym. Społeczeństwem, w którym nikt (prawie nikt) nie jest u siebie, na swoim miejscu, w swoim środowisku"16.

Traktując te rozpoznania jako punkt wyjścia i poszerzając obszar badawczego zainteresowania o inne kategorie przestrzenne związane z pograniczem, można pokusić się o sformułowanie takiej propozycji badań nad kulturą PRL, których centralnym składnikiem byłby szeroko rozumiany regionalizm i problematyka lokalna. Mieści się ona w kręgu bujnie współcześnie rozwijających się badań nad nowym regionalizmem, których - w dużym skrócie mówiąc osią jest problematyka relacji między tożsamością a terytorium. Rozważania o granicy, pograniczności, transgraniczności, relacjach centro-peryferyjnych, historyczności (czyli m.in. zakorzenieniu/wykorzenieniu) należą do najczęściej podejmowanych w tym kręgu refleksji. Rozpatrywanie kultury PRL w tym kontekście może przybierać postać co najmniej trojaką.

W pierwszym przypadku chodziłoby o prezentację lokalnej kultury i literatury w poszczególnych regionach. Dokumentacja życia literackiego w poszczególnych regionach powojennej Polski (Szczecin, Wrocław, Poznań, Warmia i Mazury, Podlasie, Śląsk) pozwoliłaby odtworzyć tradycje regionalne, reguły lokalnego życia literackiego, lokalne hierarchie artystyczne, obowiązujące tematy i konwencje pisania. Na ten temat istnieją już liczne studia szczegółowe (na przykład książka Kariera pisarza w $P R L-u^{17}$, bardzo ciekawe artykuły Małgorzaty Mikołajczak na temat powojennych dziejów literatury lubuskiej ${ }^{18}$, rozprawy Ingi Iwasiów o prozie neo-post-osiedleńczej), tego rodzaju problematyka zajmuje ważne miejsce w polu widzenia studiów regionalistycznych.

Za szczególnie ciekawą dla opisu regionalnego życia literackiego uważam okazję do prześledzenia reguł transmisji zasad (hierarchii, konwencji, tematów) z centrum do regionów (na peryferie), a także form przystosowania i oporu, jakie wobec tych transferów przejawiali autorzy lokalni oraz, w szerszym planie, analizy relacji między wzorcami narzucanymi przez kulturalne i decyzyjne centrum tamtej epoki a potrzebami emancypacyjnymi lokalnych środowisk literackich. W tej drugiej sytuacji literatura spełnia podobną rolę, co inne formy budowania lokalnej, regionalnej tożsamości. W kręgu socjologii literatury mieściłaby się także refleksja dotycząca pozycji pisarza w lokalnym środowisku, personalnych uwikłań, a także mechanizmów nobilitacji, przekraczania granic lokalności, wchodzenia w ponadlokalne formy literackiego życia.

Zasad życia literackiego dotyczy także drugi obszar refleksji historycznoliterackiej poświęconej literaturze PRL, zasługującej na badawczą refleksję, a wychodzącej od kategorii regionalnych. Mam na myśli reguły, mechanizmy, zależności pozawarszawskiego życia literackiego, które po roku 1956 i dzięki działalności popularyzatorskiej środowiska „Współczesności” nabrało rozmachu. Okrzepnąwszy instytucjonalnie w niezliczonych konkursach poetyckich,

\footnotetext{
${ }^{16} \mathrm{R}$. Nycz, PRL: pamięć podzielona, społeczeństwo przesiedlone, s. 9.

${ }^{17}$ Red. E. Dąbrowicz, K. Budrowska, K. Kościewicz, M. Budnik, Warszawa 2014.

${ }^{18}$ Chociażby Nie-miejsca pod arkadyjskim szyldem, „Teksty Drugie” 2013, nr 3, s. 245-256.
} 
lokalnych przedsięwzięciach (turnieje, konkursy, wieczory poetyckie, spotkania z uczniami, wydawnictwa i periodyki), w krótkim czasie stało się masowe. Istniejąc na pograniczu twórczości amatorskiej i „profesjonalnej”, wykreowało (i czyni to nadal, gdyż jest to zjawisko również współczesne) własne, częściowo niezależne od centralnych, hierarchie i literackie gwiazdy, których nazwiska rzadko trafiają do opracowań. Przed laty wiele krytycznych słów poświęcił temu zjawisku Stanisław Barańczak, miało ono jednak swoich obrońców (A.K. Waśkiewicz, J. Leszin-Koperski).

Trzecią możliwość wykorzystania kategorii regionalistycznych (koncepcji pogranicza) do badania powojennej kultury polskiej wskazuje Ryszard Nycz w cytowanym już artykule, kiedy postuluje poszukiwanie w literaturze PRL zapisu utraty swojego miejsca w wyniku przesiedleń, rozerwania tradycyjnej tkanki społecznej.

Podobne zakotwiczenie teoretyczne (studia nad pograniczami i transgranicznością) ma przedstawiona przez tego samego badacza koncepcja możliwej historii literatury. Sięgając po hipotezę Bohdana Jałowieckiego, która głosi, że w obrazie historii całej Polski od XIX wieku dominują dzieje zaboru rosyjskiego wraz z kanonem patriotycznych wartości, bohaterów i wydarzeń (oczywiście kosztem tradycji pozostałych regionów), Nycz wskazuje na interesujące perspektywy badawcze, jakie ona otwiera: „sięgające od historycznych studiów nad kształtowaniem się owego «kongresówkowego» obrazu XIX-wiecznej Polski, po współczesne walki symboliczne w sferze polityki historycznej i polityki pamięci"19. Regionalizacja opowieści o PRL służyć może przedstawieniu tych obszarów literatury i życia literackiego, które stanowią alternatywę dla dominującej narracji o polskiej przeszłości wywodzącej się z doświadczeń inteligencji zaboru rosyjskiego. W tym kontekście mieści się także, jak sądzę, powojenna kultura tzw. Ziem Odzyskanych, której ważnym składnikiem, wymuszonym przez aparat propagandy, było zacieranie pamięci historycznej i narzucanie słusznej ideologicznie opowieści o przeszłości ${ }^{20}$.

Badanie literatury i kultury PRL przez pryzmat regionalistyczny (geopoetyki) ma spory potencjał rewindykacyjny - otwiera możliwość mówienia o tych zjawiskach powojennej kultury, które zazwyczaj znajdowały się na marginesie zainteresowań krytyki literackiej i historii literatury: kultury lokalnej, regionalnych form i mechanizmów życia literackiego, również amatorskiego, pozwala dostrzec doświadczenie przesiedleń i fakt dominacji perspektywy „kongresówkowej" w kulturze ogólnej.

Natomiast obie przedstawione propozycje badań nad kulturą PRL stanowią przykład rozwiązań niespecyficznych, możliwość ich stosowania w interpretacji kultury innego okresu literackiego jest oczywista. W obu wypadkach mamy także do czynienia z koncepcjami wyrosłymi ze zmian w humanistyce, które mieszczą się w obszarze kulturowej historii literatury. Zarówno studium jednego roku, jak i perspektywa regionalistyczna traktują dzieło literackie jako tekst

\footnotetext{
${ }^{19}$ R. Nycz, Możliwa historia literatury, [w:] Na pograniczach literatury, red. J. Fazan, K. Zajas, Kraków 2012, s. 31.

${ }^{20}$ Znakomitym wprowadzeniem do powojennych dziejów idei regionalistycznej jest artykuł Małgorzaty Mikołajczak Wstęp: Regionalizm w polskiej refleksji o literaturze (zarys problematyki i historia idei), otwierający antologię Regionalizm literacki w Polsce. Zarys historyczny i wybór źródeł (red. Z. Chojnowski, M. Mikołajczak, Kraków 2016), jak również liczne zawarte w samej antologii teksty źródłowe.
} 
kulturowy (jeden z wielu), przyjmują perspektywę widzenia pojedynczego człowieka, przeciwstawiają się językom oficjalnym, teoriom wspólnotowym, ideom sprzyjającym kulturowej homogenizacji. W tym celu odwołują się do kategorii doświadczenia (pamięci) jako narzędzia poznawczego. Ta zbieżność jest zasadniczo przypadkowa, widzieć w niej prawdopodobnie należy świadectwo trwałości i nieuchronności zmian, jakie zachodzą w badaniach literackich. 


\title{
SŁOWA KLUCZOWE:
}

\author{
regionalizm
}

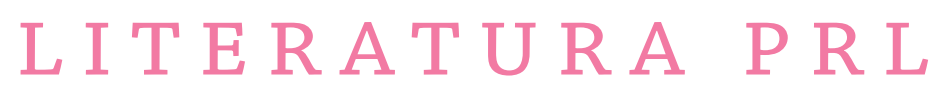

kultura lokalna

\begin{abstract}
AbSTRAKT:
Celem artykułu jest prezentacja dwu przykładowych sposobów pisania o literaturze okresu PRL i, w szerszym kontekście, dwu form uprawiania historii literatury jako takiej. Wskazując na podstawowe przesłanki istnienia współczesnej historii literatury (utrata neutralności języka badawczego, nieostrość granic przedmiotu badań literaturoznawczych, zmieniona sytuacja nauk humanistycznych), autor artykułu prezentuje formę studium jednego roku (a single year study) oraz badania inspirowane koncepcjami nowego regionalizmu. Dają one możliwość prześledzenia tematyki dotąd słabo obecnej w badaniach nad kulturą PRL (kultura lokalna, relacje między kulturą oficjalną i lokalną, trwałość podziałów porozbiorowych w kulturze powojennej) oraz przybliżenia powojennego doświadczenia poprzez wieloaspektową prezentację pojedynczego momentu w czasie (studium jednego roku).
\end{abstract}




\section{historia literatury}

\section{studium jednego roku}

\section{NOTA O AUTORZE:}

Jan Galant - dr hab., profesor w Instytucie Filologii Polskiej Uniwersytetu im. Adama Mickiewicza w Poznaniu. Jego zainteresowania naukowe dotyczą historii literatury i kultury polskiej XX wieku, zwłaszcza okresu PRL, oraz problematyki nowego regionalizmu. Opublikował książki: Marek Hłasko (Poznań 1996), Polska proza lingwistyczna. Debiuty lat siedemdziesiątych (Poznań 1999), Zszywacze, spinacze, pinezki. Krótkie szkice o literaturze (Ostrów Wielkopolski 2007), Odmiany wolności. Publicystyka, krytyka i literatura polskiego Października (Poznań 2010), redagował tomy zbiorowe: Powroty Iwaszkiewicza (Poznań 1999), PRL - świat (nie) przedstawiony (Poznań 2010). Pokolenie „Wspótczesności”. Twórcy. Dzieła. Znaczenie (Poznań 2016). W latach 2014-2016 uczestniczył w cyklu konferencji w ramach grantu Nowy regionalizm $w$ badaniach literackich. 